\title{
BENEFITS OF LEED CERTIFICATION IN TERMS OF WATER EFFICIENCY IN HOTEL INDUSTRY: A LITERATURE REVIEW
}

\author{
DAMSARI A.G.U. ${ }^{1}$, SRIDARRAN P. ${ }^{2} \&$ ABDEEN F.N. ${ }^{3}$ \\ 1,2,3University of Moratuwa, Colombo, Sri Lanka \\ 'udatharadamsari@gmail.com, 2psridarran@gmail.com,3nisharaabdeeno4@gmail.com,
}

\begin{abstract}
Water is the world's most precious resource, vital for humanity and the remainder of the world. Due to the incredible water consumption in the hotel industry, hoteliers are required to pay more concern on water saving. The water consumption of the hotel is directly influenced by existing water efficiency practices. Green Building Rating Systems (GBRS) provides a structure or collections of metrics to determine the level of water efficiency achievable by a building. Therefore, the purpose of the study is to identify how LEED certification guide hoteliers to achieve water efficiency. The literature synthesis highlights the water efficiency practices, which should be followed by the hoteliers in order to obtain LEED certification. Accordingly, it guides hoteliers to achieve water efficiency under four categories such as outdoor water usage reduction, indoor water usage reduction, cooling tower water usage reduction and water metring. Further, the study identifies the performance gaps between LEED certified hotels and non-LEED certified hotels by highlighting the water efficiency practices adapted by worldwide LEED certified hotels. Moreover, the study revealed that LEED is the most adaptable system used in Sri Lanka among other green rating systems due to its glob-al recognition. The findings of this study could be used by hoteliers as a basis in understanding the available water efficiency practices and measures for the hotels that could be utilised in achieving water efficiency.
\end{abstract}

Keywords: Water Efficiency, Green Building Rating System (GBRS), Leadership in Energy and Environment Design (LEED)

\section{Introduction}

Water is the most valuable global commodity, which provides multiple benefits for people (White et al., 2010). The hotel industry consumes substantial amounts of water from complete water use because Wong, 2014). The water consumption of the hotel depends not only on the nature, quality and size of the hotel but also on the facilities given, the weather and current procedures in the hotel for water conservation (Erdogan \& Baris, 2007). Pratt (2014) stated that GBRS provide frameworks or sets of metrics to assess the water efficiency level a construction can achieve. There are several green ranking systems used in Sri Lanka and LEED is the most versatile system due to its global recognition (Rodrigo \& Jayarathne, 2012). According to Walsman (2014), LEED certification helps to cut operating costs and improve the revenues of the hotel. The sum of the savings obtained by achieving LEED certification caused to increase the annual revenue (Ribero, Garzon, Alvarado, \& Gasch, 2016). Also, LEED certified hotels are more attractive to hoteliers because of water saving and energy saving through mechanisms and better environment (NICHOLS, 2017). However, poor performance of LEED certified building also can be identified when compared to non-LEED certified building are also evident due to the of misuse of available conservation systems accredited by the LEED certification (Orr, 2014). Further the author stated that LEED buildings perform no better, and in fact perform worse, than non-LEED buildings.

Several researches had been carried out regarding water saving strategies in the hotel industry, water efficiency in green building and non-green buildings in the apparel sector. Those studies discovered that general practices used by LEED and Non-LEED hoteliers to manage their water consumption. Yet, there is a lack of concern on the comparative study of water efficiency practices regarding the LEED certified hotel building and Non-LEED certified hotel building in Sri Lanka. Therefore, the problem emerges from a comparison between LEED certified and Non-LEED certified hotels water efficiency practices to identify the benefits of LEED certification. 


\section{Methodology}

A systematic analysis of literature expedites the researcher to enhance the research base by consolidating the existing knowledge from around the study area. Kumar (2011) declared that a comprehensive literature synthesis helps to establish the theoretical roots of the study, clarify the ideas and develop the research journey. Therefore, the researcher can identify the link between what the researcher is proposing to examine and what has already been studied.

Hence, a rigorous theoretical study was conducted to investigate the diverse water efficiency criteria of LEED certification and established the advantages of LEED certification for the hotel industry in Sri Lanka by referring research articles, conference proceedings, newspaper articles, thesis and respective websites. Among the available search engines, 'Google Scholar', 'Scopus', 'Emerald', and 'Science direct' were selected for this study, as these domains have been widely used in similar reviews (e.g. Yang et al., 2009). Furthermore, the water efficiency practices used by the LEED certified hotels were identified through the literature synthesis. Compiling the extensive literature findings, a conceptual framework was developed to identify the water efficiency requirements of LEED certification and how the LEED certification is involving to enhance the water efficiency in the hotel industry.

\section{Water efficiency in hotel industry}

Hoteliers can save money and increase their profits by taking simple measures to save water and energy in the hotel premises (Fountain, 2015). The water consumption of a hotel is a different hotel to hotel (NYC Environmental Protection, 2018). In order to achieve water efficiency in the hotel, there are several water conservation strategies can be followed. The Table 1 shows the water efficient strategies used by the hotel.

Table 1- Strategies to Achieve Water Efficiency in Hotel Building

\begin{tabular}{|c|c|c|}
\hline $\begin{array}{l}\text { Water } \\
\text { Efficiency } \\
\text { Strategies }\end{array}$ & Description & Reference \\
\hline $\begin{array}{l}\text { Water } \\
\text { Management } \\
\text { Plan }\end{array}$ & $\begin{array}{l}\text { This is a water-saving action program that provides details on current } \\
\text { water usage and describes water efficiency improvement procedures, } \\
\text { water conservation strategies, and water conservation targets. }\end{array}$ & $\begin{array}{l}\text { (US Department of } \\
\text { Energy, 2019) }\end{array}$ \\
\hline $\begin{array}{l}\text { Green Building } \\
\text { Rating System }\end{array}$ & $\begin{array}{l}\text { Water efficiency is one of the key parameter which should be full-filled } \\
\text { by the building which is planning to get the Green Rating certification. } \\
\text { Therefore, it encourages people to enhance water efficiency in the } \\
\text { building. }\end{array}$ & $\begin{array}{l}\text { (Waidyasekara and } \\
\text { Silva, 2013) }\end{array}$ \\
\hline $\begin{array}{l}\text { Water } \\
\text { Hierarchy }\end{array}$ & $\begin{array}{l}\text { It performs as a guide to changes the water efficiency in qualitatively as } \\
\text { well as quantitatively. It is a guideline for qualitative and quantitative } \\
\text { prioritization of process changes. The WMH consists of five levels, } \\
\text { namely (1) source elimination, (2) source reduction, (3) direct } \\
\text { reuse/outsourcing of external water, (4) regeneration, and (5) use of } \\
\text { fresh water. }\end{array}$ & (Wan Alwi et al., 2014) \\
\hline Water Metering & $\begin{array}{l}\text { Water metering provides the operations and maintenance transparency } \\
\text { needed to manage water resources more efficiently. The information } \\
\text { provided by metering of water can encourage behavioural reductions in } \\
\text { consumption by increasing consumer knowledge about their resource } \\
\text { use. }\end{array}$ & (Berger et al., 2016) \\
\hline Water Audits & $\begin{array}{l}\text { A water audit is a survey that all water uses or transports equipment, } \\
\text { plumbing, equipment and practices in a business or manufacturing } \\
\text { facility to determine the current water uses, losses and conservation } \\
\text { practices and recommend improvements. It serves as a starting point to } \\
\text { identify losses and implement useful practices in water efficiency. }\end{array}$ & $\begin{array}{l}\text { (New Hampshire } \\
\text { Environmental } \\
\text { Service, 2013) }\end{array}$ \\
\hline Faucet Aerators & $\begin{array}{l}\text { A faucet aerator that has low-flow and high-efficiency reduce the water } \\
\text { usage by } 4 \% \text {. Making the switch can potentially save more than } 500 \\
\text { gallons of water each year. }\end{array}$ & (Preston, 2019) \\
\hline Low Flow Tap & $\begin{array}{l}\text { Low-flow taps operate by adding air into the flow of water. By using this } \\
\text { low flow tap, it provides the feeling of complete water flow, even though } \\
\text { the amount of water is significantly lowered. }\end{array}$ & $\begin{array}{l}\text { (Australian } \\
\text { Government, 2018) }\end{array}$ \\
\hline
\end{tabular}


Adapted from: (US Department of Energy, 2019; Waidyasekara \& Silva, 2013; Wan Alwi et al., 2014; Berger et al., 2016; New Hampshire Environmental Service, 2013)

\section{Green Building Rating Systems}

GBRS are the certification systems that concentrate on the project as a whole beyond the product (Vierra, 2014). Doan et al. (2017), identified various types of globally recognised GBRS to assess the building efficiency. GBRS is intended to determine and assess building efficiency from planning, design, construction and activities (Sachin \& Jha, 2012). In Sri Lanka, mainly adopted systems are LEED certification and Green SL certification.

\subsection{LEED}

As per the U.S. Green Building Council (2017), LEED or Leadership in Energy and Environmental Design is the most universally used green ranking system in the world. Moreover, the authors emphasised that the LEED certification system evaluate six aspects; Sustainable sites, Water efficiency, Energy efficiency, Material, Indoor Environment Quality and Innovations, when giving the certification for buildings.

\subsection{GREEN SL}

Green SL rating system was initiated by Green Building Council Sri Lanka based on the LEED certification (Kumanayake, Luo and Paulusz, 2018). In addition, the researcher noted that the Green SL rating system for existing buildings is a collection of performance standards for accrediting the operation and maintenance of commercial or industrial buildings.

\section{Different Water Efficiency Requirements of LEED Certification}

The water efficiency classification under the LEED certification focuses specifically on water use reduction, water efficient landscaping and innovative wastewater technologies (Gurgun, Komurlu and Arditi, 2013). According to the US Green Building Council (2019), the requirements should be full filled to get the LEED certification can be described as follows.

\subsection{PREREQUISITES}

These requirements are something that is necessary to an end or to the carrying out of a function. Therefore, to get the LEED certification, the building should be achieved following requirements earlier. It also add value when calculating the credits under the LEED certification.

\subsubsection{Outdoor Water Use Reduction}

This requirement describe that how to build up the facility to reduce the future (operation Phase) outdoor water consumption. According to the US Green Building Council (2019), the facility should be fulfilled the reduction of outdoor water usage through one of the following options.

Option 1: No irrigation required

Beyond a fixed establishment duration of two years, the landscape does not require a permanent irrigation system.

Option 2: Reduced irrigation

Landscape water use for peak irrigation at the site may be reduced by at least $30 \%$ from the baseline measurement. The reduction of water must be done by plant species and the effectiveness of the 
irrigation system. Two additional points can be earned by reducing the prerequisite water requirement. The point allocation for additional outdoor water conservation can be shown as follows.

Table 1: Points for Reducing Irrigation Water

\begin{tabular}{|l|l|}
\hline Percentage reduction from baseline & Points \\
\hline $\mathbf{5 0 \%}$ & 1 \\
\hline $100 \%$ & 2 \\
\hline
\end{tabular}

(Source: US Green Building Council, 2019)

\subsubsection{Indoor Water Use Reduction}

The aim of this prerequisite is reducing the indoor water consumption before the operation of the facility. All recently installed washrooms, urinals, private wash faucets and showerheads should be labelled with Sense water (SLOANE Global Holdings, 2016). The basic water consumption of fixtures and fittings can be shown in Table 3 below.

Table 2: Baseline Water Consumption of Fixtures and Fittings

\begin{tabular}{|l|l|}
\hline $\begin{array}{l}\text { Commercial Fixtures, Fittings, and } \\
\text { Appliances }\end{array}$ & Current Baseline (SI units) \\
\hline Water closets (toilets) & 6 liters per flush (lpf) \\
\hline Urinal & 3.8 Liters per Flush (lpf) \\
\hline Public lavatory (restroom) faucet & $\begin{array}{l}1.9 \text { Liters per Minute (lpm) at } 415 \mathrm{kPa} \text {, all others } \\
\text { except private applications }\end{array}$ \\
\hline Private lavatory faucet & 8.3 Liters per Minute (lpm) at $415 \mathrm{kPa}$ \\
\hline $\begin{array}{l}\text { Kitchen faucet (excluding faucets used } \\
\text { exclusively for filling operations) }\end{array}$ & $8.3 \mathrm{lpm}$ at $415 \mathrm{kPa}$ \\
\hline Showerhead & $9.5 \mathrm{lpm}$ at $550 \mathrm{kPa}$ per shower stall \\
\hline
\end{tabular}

(Source: US Green Building Council, 2019)

Moreover, the US Green Building Council emphasised that water consuming appliances, equipment, and processes must meet the requirements listed in the following Table 4 .

Table 3: Standards for Appliances

\begin{tabular}{|c|l|l|}
\hline \multirow{2}{*}{ Appliance } & \multicolumn{1}{|c|}{ Type } & \multicolumn{1}{c|}{ Requirement (SI units) } \\
\hline \multirow{3}{*}{ Dishwasher } & Under counter & $\leq 6.0$ liters/rack \\
\cline { 2 - 3 } & Stationary, single tank, door & $\leq 5.3$ liters/rack \\
\cline { 2 - 3 } & Single tank, conveyor & $\leq 3.8$ liters/rack \\
\cline { 2 - 3 } & Multiple tank, conveyor & $\leq 3.4$ liters/rack \\
\cline { 2 - 3 } & Flight machine & $\leq 680$ liters/hour \\
\hline \multirow{2}{*}{ Food steamer } & Batch & $\leq 23$ liters/hour/pan \\
\cline { 2 - 3 } & Cook-to-order & $\leq 38$ liters/hour/pan \\
\hline \multirow{2}{*}{ Combination oven } & Countertop or stand & $\leq 13$ liters/hour/pan \\
\cline { 2 - 3 } & Roll-in & $2019)$ \\
\hline
\end{tabular}

(Source: US Green Building Council, 2019) 


\subsubsection{Building Level Water Metering}

As a precondition for receiving water efficiency points, LEED has introduced a building level water metering standard (Harbour, 2016). According to the US Green Building Council (2019), permanent water meter installation will calculate the maximum use of the building's potable water and associated grounds. Monthly or annual meter readings must be collected manually or automatically. It also notes that this commitment will continue for a period of five years or until the building changes ownership or the lessor.

\subsection{ADDITIONAL REQUISITES}

Once the facility has fulfilled all the preconditions, there are four places where additional LEED credit points can be received by the facility.

\subsubsection{Outdoor Water Usage}

Eliminating the need for an outdoor irrigation system fully or increasing the need for landscape water by at least $50 \%$ will receive up to 2 points (SLOANE Global Holdings, 2016).The $50 \%$ reduction of water can be accomplished from the approximate base point for the site's peak irrigation month by selecting plant species and active irrigation systems (US Green Building Council, 2019). In addition, the article highlighted that any combination of capacity, alternative water sources and intelligent scheduling technologies could achieve additional reductions above $30 \%$.

\subsubsection{Indoor Water Usage}

A building can gain up to six points for LEED certification by using high-efficiency components and alternative water resources to go beyond the precondition (Southerland, 2015). In addition, the author clarified that water recycling supports the pilot credit for sustainable waste water management, which aims to reduce waste water use by 50\% from a baseline. As stated in US Green Building Council (2019), required water reduction percentages and its credit allocation can be shown following Table 5 .

Table 4: Points for Reducing Water Use

\begin{tabular}{|l|l|}
\hline $\begin{array}{l}\text { Percentage } \\
\text { reduction }\end{array}$ & $\begin{array}{l}\text { Points (CI Hospitality } \\
\text { Industry) }\end{array}$ \\
\hline $25 \%$ & 2 \\
\hline $30 \%$ & 4 \\
\hline $35 \%$ & 6 \\
\hline $40 \%$ & 8 \\
\hline $45 \%$ & 10 \\
\hline $50 \%$ & 11 \\
\hline
\end{tabular}

(Source: US Green Building Council, 2019)

\subsubsection{Cooling Tower Water Use}

The main aim is to maintain the water requirement of the cooling tower while regulating bacteria, oxidation and scale in the condenser water system (US Green Building Council, 2019). Evaporative condensers that are more energy efficient than traditional condensing systems due to evaporative systems can reduce air temperature more quickly and do not lose air humidity (Western Cooling Efficiency Center of the University of California Davis, 2011). Completing this sort of evaporative condenser would allow up to two points for a project (Southerland, 2015). For cooling towers and evaporative condensers, one time potable water study can be undertaken to optimize cooling tower cycles. The points are allocated according to the number of cooling tower cycles and following Table 6 describes that the credit allocation. 
Table 5: Points for Cooling Tower Cycles

\begin{tabular}{|l|l|}
\hline Cooling tower cycles & Points \\
\hline $\begin{array}{l}\text { Maximum number of cycles reached without reaching any rate of filtration or } \\
\text { affecting condenser water system operation (up to maximum of 10 cycles) }\end{array}$ & 1 \\
\hline $\begin{array}{l}\text { Achieve a minimum of 10 cycles by increasing the level of treatment in condenser or } \\
\text { make-up water or achieve the number of cycles for 1 point and use a minimum 20\% } \\
\text { recycled non potable water }\end{array}$ & 2 \\
\hline
\end{tabular}

(Source: US Green Building Council, 2019)

\subsubsection{Water Metering}

Water metering is a new LEED version 4 credit that mainly focuses on water sub metering in the building (Western Cooling Efficiency Center of the University of California Davis, 2011). As stated in US Green Building Council (2019), two or more sub-systems such as irrigation, indoor plumbing and fittings, hot water, boilers, waste water or other process water should be installed in the sub-metering system.

\section{Water Efficient Practices in LEED Certified Hotels}

According to the Ahn and Pearce (2013) case study, two LEED platinum certified hotels in the United States were analysed to identify the water efficient strategies. The researchers further indicated that, in order to improve water efficiency both hotels have installed highly efficient water-saving appliances and fittings, including highly efficient water closets, dual flush toilets, waterless urinals and low-flow showers.

The most common ways of minimizing water consumption in the hotel industry are to replace current appliances with water-efficient elements, like cleaning facilities, toilets, showers and faucets (BrunsSmith et al., 2015). In addition, the study showed that the installation of low-flow showerheads and air-conditioned roofs saved $\$ 1.50$ per room per month for one hotel and saved 180,000 gallons of water per year using water-efficient toilets. Besides that, the hotel use grey water recycling system, water saving notices in the bathroom and a localised irrigation system to reduce water consumption (Gonzalez and Leon, 2001). ITC Grand Chola Hotel in Chennai is a LEED platinum rated hotel and it is the world's largest LEED Platinum rated Green Hotel (Tuppen, 2012). As stated in the article, the hotel is adapting following water conservation methods.

- Green roofs and water harvesting structures are used to collect storm water.

- All the irrigation activities, flushing and cooling tower operation is fulfilled using treated water.

- Using water efficient fixtures, fittings and appliances, water usage is reduced by $35 \%$ compared to conventional usage

- Choose plants that consume low water, while trees plant to reduce the loss of evaporation and thus reduce water consumption

- Use drip irrigation and timer based controls to operate the irrigation valves and prevent wastage of water

- The water from the last wash is used in the laundry to pre-wash the second cycle

- The use of environmentally friendly low acidic washing fluids helps to reduce running time and saves water

The Hyatt hotel, which has become the first LEED-certified hotel in Seattle by receiving the LEED Silver certification, achieved a $32 \%$ reduction in water use by installing low-flow showerheads, washstands and water closets, along with dual-flow toilets and other water-saving innovations (Chikushi, 2009). Cinnamon Bey Beruwala became Sri Lanka's first hotel to obtain LEED Gold certification after observing and meeting the requirements of all the sustainable standards required by a business entity (Senanayake, 2014). According to the writer, he clarified that revolutionary waterefficient landscaping system reduced the use of drinking water in the irrigation system by $100 \%$ and 
water management techniques reduced the use of water by $65,62 \%$ compared to conventional buildings.

\section{Benefits of LEED Certification for Hotel Industry}

LEED assesses the performance of the building throughout its life cycle and it is the most preferable globally accepted green rating system, which can save energy by 25\%-30\% (Moussa and Farag, 2017). According to Johnston and Breech (2011), the main reason for most hoteliers seek to gain LEED because of its operational efficiencies and revenue increase. Moreover, the authors emphasised that innumerable advantages associated with LEED certified building and those are listed below.

- Lower operating cost

Through energy efficiency and water efficiency, hoteliers can reduce utility bills. For example, the Proximity Hotel in Greensboro which is certified under LEED certification reduces the utility bill by achieving $39.2 \%$ less energy and $33.5 \%$ less water.

- Increased property value

LEED certification adds value to the property and it has a higher market value than a conventional building.

- Healthier and safer for occupants

Under the LEED certification, the building should consider the Indoor Environment Quality, lighting, and it gives a better working environment for employees.

- Certified recognition of green practices

LEED gives the physical proof of the values of the organization that owns and occupies the building. It is a market differentiator and it caused to attract the customers to the hotels.

As stated by the Verma and Walsman (2014), the LEED certified hotels obtained superior financial performance as compared to Non- LEED certified hotels. According to Leon (2016), LEED certification increase the satisfaction of guests in the hotel by giving a comfortable environment. Moreover, the LEED certification system is a transformative tool that positively impacts the triple bottom line of the hotel such as people, planet and profit (Lundin, 2016).

\section{Conceptual Framework}

Based on the literature review findings the study developed a conceptual framework to provide an overview on the impact of LEED certification in water efficiency. The developed framework is presented in Figure 2.6. It illustrates the water efficiency practices in the hotel industry, while identifying the water efficiency requirements needed to achieve when getting the LEED certification. The water efficiency requirements are categorised into pre-requisites and additional requisites. Prerequisites are presented in a purple colour box and additional requisites are summarised in a blue colour table. The aim of this study is identifying water efficiency requirements under LEED certification and establish the benefits of LEED for hotel industry, which is shown in yellow colour box. The literature findings identified the overall benefits of LEED certification, but it is not specifically identified the benefits of LEED certification specifically for water efficiency. It will be covered in future studies. 


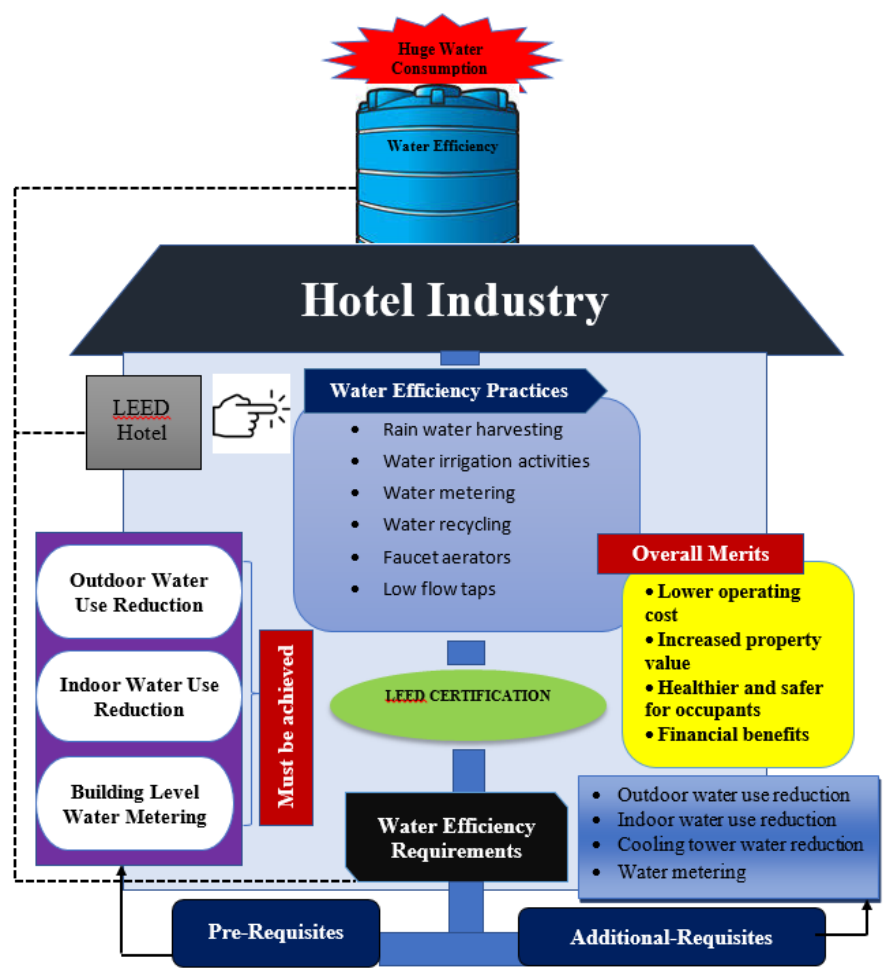

Figure 1- Conceptual Framework

\section{Conclusions and Recommendations}

There are several green building rating systems, which are focused on water efficiency in a building. Among those green building rating systems, LEED certification is the globally applicable certification system in the hotel industry. The LEED certification system evaluates six aspects; sustainable sites, water efficiency, energy efficiency, material, indoor environment quality and innovations when giving the certification for buildings. LEED is the most suitable rating system, which evaluates the water efficiency category because it focuses on the prerequisites of water efficiency before doing the reductions. A minimum of 11 points can be received in the LEED certification under the water efficiency category, which mainly focuses on water use reduction, water efficient landscaping and innovative waste water technologies. According to the progress of those sections, the points are allocated under water efficiency category.

Being a LEED certified hotel is not only beneficial for water efficiency, but for every aspects in the hotel. LEED certification assesses the performance of the building throughout its life cycle and it is the most preferable globally accepted green rating system, which save energy, water and operational cost. Therefore, most hoteliers seek to gain LEED because of its operational efficiencies and revenue increasement.

Through the identified water efficiency requirements under the LEED certification, this study discovered the benefits of LEED certification for water efficiency. Apart from that, the practical usage of those water efficiency requirements were identified by studying the worldwide case studies. Yet, the research findings were completely based on a thorough analysis of literature which leads a way forward to continue the study to explore the benefits of LEED for water efficiency and practicality of the LEED water efficiency requirements in Sri Lankan hotel industry.

\section{References}

Ahn, Y. H. and Pearce, A. R. (2013) 'Green luxury: A case study of two green hotels', Journal of Green Building, 8(1), pp. 90-119. doi: 
10.3992/jgb.8.1.90.

Australian Government (2018) Water efficiency. Available at: https://www.energy.gov.au/households/water-efficiency (Accessed: 14 March 2019).

Berger, M. A. et al. (2016) 'Exploring the energy benefits of advanced water metering', Energy Analysis and Environmental Impacts Division Energy Technologies Area, (August), p. 54. Available at:

https://www.researchgate.net/profile/Michael_Berger18/publication/311302089_Exploring_the_Energy_Benefits_of_Advanced_Water_ Metering/links/584101c908aeda696811adde.pdf.

Bruns-Smith, A. et al. (2015) Environmental sustainability in the hospitality industry: Best practices, guest participation, and customer satisfaction, Cornell Hospitality Report. Available at: http://scholarship.sha.cornell.edu/chrpubs.

Chikushi, B. K. (2009) Seattle, Hyatt, and the LEED evolution, HVS. Available at: https://www.hvs.com/article/4155-seattle-hyatt-andthe-leed-evolution.

Gonzalez, M. and Leon, C. . (2001) 'The adoption of environmental innovations in the hotel industry of Gran Canaria', Tourism Economics, 7(2), pp. 177-190. doi: 10.5367/000000001101297801.

Gurgun, A. P., Komurlu, R. and Arditi, D. (2013) 'Assessment of LEED requirements for water efficiency in developing country-specific certification', in Yazdani, S. and Singh, A. (eds) New Developments in Structural Engineering and Construction. Honolulu. doi: 10.3850/978-981-07-5354-2.

Harbour, P. (2016) Tracking and conserving facility water use - Consulting - Specifying Engineer, Consulting Specifying Engineer. Available at: https://www.csemag.com/articles/tracking-and-conserving-facility-water-use/ (Accessed: 1 May 2019).

Johnston, D. and Breech, P. (2011) 'LEED certification for hotels low cost', The Journal of Hospitality Financial and Technology

Professionals, 25(7). Available at: https://www.hftp.org/hospitality_resources/bottomline/index.cfm?file=Bottomline-2010-12_01.pdf. Kumanayake, R., Luo, H. and Paulusz, N. (2018) 'Assessment of material related embodied carbon of an office building in Sri Lanka', Energy and Buildings. Elsevier B.V., 166, pp. 250-257. doi: 10.1016/j.enbuild.2018.01.065.

Kumar, R. (2011) Research methodology. 3rd edn, SAGE Publications Ltd. 3rd edn.

Leon, I. A. (2016) 'The relationship between LEED hotel design and guest satisfaction - Cayuga Hospitality Consultants', ARA Journal of Tourism Research, 6(1). Available at: https://cayugahospitality.com/cayuga-admin/the-relationship-between-leed-hotel-design-andguest-satisfaction/ (Accessed: 6 May 2019).

Lundin, J. (2016) LEED, Emerald Skyline Corporation. Available at: http://sustainablebenefits.com/tag/leed/ (Accessed: 6 May 2019).

Moussa, R. A. and Farag, A. A. (2017) 'The applicability of LEED of new construction (LEED-NC) in the Middle East', Procedia

Environmental Sciences, 37, pp. 572-583. doi: 10.1016/j.proenv.2017.03.044.

New Hampshire Environmental Service (2013) 'Water Efficiency : Business or Industry Water Use and Conservation Audit'. Available at: https://www.des.nh.gov/organization/commissioner/pip/factsheets/dwgb/documents/dwgb-26-16.pdf.

Preston, E. (2019) 10 water saving devices you can install yourself. Available at: https://www.thespruce.com/water-saving-devicesinstall-yourself-4096495 (Accessed: 13 March 2019).

Senanayake, S. (2014) 'Cinnamon Bey becomes first hotel in Sri Lanka to win LEED Gold', Daily. Available at: http://www.ft.lk/article/285666/Cinnamon-Bey-becomes-first-hotel-in-Sri-Lanka-to-win-LEED-Gold (Accessed: 3 May 2019). SLOANE Global Holdings (2016) LEED v4 water efficiency credits: Do you know the new standards?, Sloane Blog. Available at: https://www.sloan.com/blog/leed-v4-water-efficiency-credits-do-you-know-new-standards (Accessed: 30 April 2019).

Southerland, L. B. (2015) 'Maximizing energy and water credits under LEED V. 4', Energy Engineering: Journal of the Association of Energy Engineering, 112(5), pp. 18-32. doi: 10.1080/01998595.2015.11449890.

Tuppen, H. (2012) LEED platinum: ITC Grand Chola, Green Hotelier. Available at: http://www.greenhotelier.org/our-themes/newbuilds-retro-fits/best-practice-itc-grand-chola/ (Accessed: 3 May 2019).

US Department of Energy (2019) Best management practice : Water management planning. Available at:

https://www.energy.gov/eere/femp/best-management-practice-1-water-management-planning (Accessed: 13 March 2019).

US Green Building Council (2019) LEED credit library. Available at: https://www.usgbc.org/credits/hospitality---new-construction/v4 (Accessed: 28 April 2019).

Verma, R. and Walsman, M. (2014) It's not just cost savings: LEED certification boosts hotel revenue too, U.S. Green Building Council. Available at: https://www.usgbc.org/articles/it's-not-just-cost-savings-leed-certification-boosts-hotel-revenue-too (Accessed: 6 May 2019).

Waidyasekara, K. G. A. S. and Silva, M. L. D. (2013) 'Comparative study of green building rating systems in terms of water efficiency and conservation', The Second World Construction Symposium 2013: Socio-Economic Sustainability in Construction. Available at: http://www.irbnet.de/daten/iconda/CIB_DC26706.pdf.

Wan Alwi, S. R. et al. (2014) 'Benchmarking water utilisation using minimum water network technique'.

Western Cooling Efficiency Center of the University of California Davis (2011) Annual report on cooling in the west 2011. California. Available at: https://wcec.ucdavis.edu/wp-content/uploads/2013/01/AnnualReport_2012_Web.pdf. 